\title{
Sugarcane straw management and its impact on production and development of ratoons
}

\author{
Gisele Silva de Aquino ${ }^{a, *}$, Cristiane de Conti Medina ${ }^{a}$, Dairi Cortez da Costa ${ }^{a}$, \\ Muhammad Shahab ${ }^{\mathrm{a}}$, Antonio Dias Santiago ${ }^{\mathrm{b}}$ \\ a Londrina State University, Rodovia Celso Garcia Cid - PR 445, Km 380, PO Box 10.011, 86051-990 Londrina, PR, Brazil \\ b Embrapa Tabuleiros Costeiros, PO Box 2.013, 5706191 Maceió, AL, Brazil
}

\section{A R T I C L E I N F O}

\section{Article history:}

Received 24 May 2016

Received in revised form 22 February 2017

Accepted 11 March 2017

\section{Keywords:}

Saccharum spp

Agricultural waste

Biomass

Biometry

Soil cover

Growing under straw

\begin{abstract}
A B S T R A C T
Due to mechanical harvesting large amount of straw is left in the field which implicates modification throughout the agriculture environment. This straw is beneficial for both soil and plant. However, there is no information about the sufficient quantity which can be used to achieve such effects and also whether it can be used in other sectors like electricity and ethanol production. Therefore, a research was designed with the objective to evaluate the effect of different amounts of straw on the development and productivity of sugarcane during the first and second ratoons. Treatments used in the experiment included: burned cane, $0 \%, 25 \%, 50 \%, 75 \%$ and $100 \%\left(20 \mathrm{tha}^{-1}\right)$ of sugarcane straw left on the soil surface. The tested variables included leaf area index (LAI), number, diameter, length and production of stems. Plants were evaluated at 60,120,180, 240 and 370 days after harvest (DAH) for the first ratoon and at 60, 120, 180, 240 and $270 \mathrm{DAH}$ for the second ratoon. Replacing burned cane harvest system for soil management with straw promotes the development and productivity of sugarcane ratoons. Field managements with burned cane, total removal of the straw, or keeping $25 \%$ of straw result in low number of tillers, leaf area index, stem diameter and productivity of sugarcane ratoons, under water stress conditions. Whereas keeping $50 \%$ of straw mulch is enough to improve the growth and yield of sugarcane with drought occurrences, while the remaining $50 \%$ can be used for second generation of ethanol production or electricity without damaging the crop yield.
\end{abstract}

(c) 2017 Elsevier B.V. All rights reserved.

\section{Introduction}

Sugarcane (Saccharum spp.) is grown in over 121 countries and is a good source for the production of sugar and ethanol. Over $80 \%$ of the sugar produced in the world is obtained from sugarcane, whereas Brazil, India, China and Thailand account for $60 \%$ of the total production (FAO, 2016). The major sugarcane producing areas of world have recently adopted the practice of mechanical harvesting (Cardoso et al., 2013; Unica, 2015). In this system, dry leaves, tips and green leaves are cut off and thrown on the soil surface forming a straw that acts as mulch over soil surface. In Brazil between 10 to $30 \mathrm{Mg} \mathrm{ha}^{-1}$ of straw is left in the field after harvest, depending on the variety and age of the sugarcane field (Oliveira et al., 2003).

\footnotetext{
* Corresponding author.

E-mail addresses: gisele.s.aquino@hotmail.com (G.S. de Aquino), medina@uel.br (C. de Conti Medina), dairi_698@hotmail.com

(D.C. da Costa), mshahab78@gmail.com (M. Shahab), antonio.santiago@embrapa.br (A.D. Santiago).
}

More than 300 million Mg of straw is produced per year worldwide (Unica, 2015).

This layer of plant residue over the soil surface is very useful for the production system, promoting better water infiltration into the soil, stabilizing the temperature and lowering the evaporation from surface layer, altering of light incidence to the surface, better control of erosion, increase in the organic matter contents of the soil and improvement of soil structure (Inman-Bamber and Smith, 2005; Garcia et al., 2007; Christoffoleti et al., 2007; Cavenaghi et al., 2007; Guimarães et al., 2008; Tavares et al., 2010; Cardoso et al., 2013; Costa et al., 2014). From an environmental perspective Otto et al. (2016) reviewed recent developments in $\mathrm{N}$ management for sugarcane-biofuel production and verified that, the transformation of nitrogen $(\mathrm{N})$ fertilizers into $\mathrm{N}_{2} \mathrm{O}$ gases can give the same advantages and could replace fossil fuels with biofuels. However, maintaining straw over soil surface and crop rotation with $\mathrm{N}$-fixing legume can potentialy reduce the $\mathrm{N}$ requirements of sugarcane crop which is very important for sustainable biofuel production.

Factors like emergence, bud sprout and plant growth are also influenced by changes in the crop environment (Franchini et al., 
2012). It is also important to mention that the sugarcane varieties available today were developed at a time when burned cane harvesting system was in practice, and many of them respond differently to the mechanical harvest system (Souza et al., 2005).

Campos (2010) evaluated the tillers, fresh biomass accumulation and productivity of ratoon sugarcane (var. RB855453) under straw management in Oxisol and reported that keeping sugarcane straw over the entire field showed negative effect on ratoon development which led to low tiller biomass and productivity. However, Ball Coelho et al. (1993) observed that leaving the straw on soil surface (oxic Argisol) caused 43\% increase in dry matter production of the first sugarcane ratoon. Oliveira et al. (1995) and Resende et al. (2006) also reported that keeping straw over the soil surface has beneficial effect, however, it was not mentioned that how much straw is needed to achieve such effects and that what is the effect of small straw quantity.

Calculating the amount of straw needed as soil cover for the development of sustainable and optimized sugarcane production enables the surplus to be used for electricity or second generation ethanol production, which can play an important role in the global energy grid. It is estimated that the use of straw can triplicate the ethanol production without the need to increase the planting area, keeping in mind that one ton of straw can produce 270 liters of ethanol, and one ton of sugarcane can produce 80 liters of ethanol (Santos et al., 2012). Marin et al. (2016) reported that in order to meet the demands of the country by 2024, Brazil which is the world highest producer of sugar and ethanol, has to expand its area by $45 \%$ and that studies aimed at increasing productivity are urgent and necessary.

This study aimed to evaluate the effect of different amounts of straw mulching on the development and productivity of sugarcane during the first and second ratoons.

\section{Material and methods}

The experiment was conducted in an area that belong to the Bandeirantes Sugar and Alcohol Plant, located in the city of Bandeirantes, latitude $23^{\circ} 06^{\prime} \mathrm{S}$, longitude $50^{\circ} 21^{\prime} \mathrm{W}$ and altitude of $440 \mathrm{~m}$. Based on the Koeppen climatic classification, the climate of the region is $\mathrm{Cfa}$, with an average annual rainfall of $1.300 \mathrm{~mm}$. The average annual insolation is $7.14 \mathrm{~h}^{-1}$ day.

The area where the experiment was conducted has been cultivated with sugarcane for the last 65 years. During this period, manual method of harvesting (burned cane harvesting system) was used until 2010, when it was replaced by the mechanical harvesting system.

The experiment was carried out using randomized block design with four replications, during the first and second ratoon cycles of sugarcane (Saccharum spp. variety SP 801816). The climatological water balance (Fig. 1) during the trial implementation period, was calculated using Thornthwaite and Mather (1955) method. Data of average monthly temperature and total monthly rainfall were provided by the meteorological station of the Agronomic Institute of Paraná (IAPAR), located in Bandeirantes city, two kilometers from the experimental site. The value of available water capacity (AWC) considered was $100 \mathrm{~mm}$.

The soil is classified as Oxisol (Embrapa, 2013), with a texture $61 \%$ of clay; $2 \%$ silt and $37 \%$ sand, calculated using particle size analysis. The soil was chemically analyzed and a layer of $0-0.2 \mathrm{~m}$ depth showed the following results: Organic matter $\left(\mathrm{g} \mathrm{kg}^{-1}\right) 34.2$; $\mathrm{P}\left(\mathrm{mg} \mathrm{dm}^{-3}\right.$ - extractor Melich) 39.9; $\mathrm{K}\left(\mathrm{Cmolc} \mathrm{dm}^{-3}\right)$ 3.0; Ca $\left(\mathrm{Cmolc} \mathrm{dm}^{-3}\right)$ 7.8; $\mathrm{Mg}\left(\mathrm{Cmolc} \mathrm{dm}^{-3}\right)$ 1.8; $\mathrm{H}+\mathrm{Al}\left(\mathrm{Cmolc} \mathrm{dm}^{-3}\right)$ 3.0; CEC $\left(\mathrm{Cmolc} \mathrm{dm}^{-3}\right)$ 15.7; pH $\left(\mathrm{CaCl}_{2}\right) 5.6$ and V (\%) 80.8.

Before the plantation, $70 \mathrm{Mg} \mathrm{ha}^{-1}$ of filter cake was applied to the field area as a common practice. Similarly, $150 \mathrm{~m}^{3}$ of vinasse was also applied for the last crop to supply the potassium extracted by the previous crop (Barbosa et al., 2013). The bulk density $\left(\mathrm{g} \mathrm{cm}^{3}\right.$ ) of different layers analyzed at the same period of time is as follows: $0-0.10 \mathrm{~m}$ depth: $1.33 ; 0.10$ to $0.60 \mathrm{~m}: 1.30$, indicating no physical obstacle to the development of the roots. The land was prepared for cultivation using a disk harrow and light harrowing.

Each plot consisted of 10 sugarcane lines with a length of $10 \mathrm{~m}$ each (10 lines $\times 10 \mathrm{~m})$, totaling 100 linear $\mathrm{m}$ with spacing of $1.50 \mathrm{~m}$ between the lines. For data collection, six central rows were used with nine linear meters, totaling 54 linear meters. Treatments which were evaluated during the experiments are as follows: burned sugarcane (where $100 \%$ of straw was burned), 0\%, 25\% (5 $\left.\mathrm{Mg} \mathrm{ha}^{-1}\right), 50 \%\left(10 \mathrm{Mg} \mathrm{ha}^{-1}\right), 75 \%\left(15 \mathrm{Mg} \mathrm{ha}^{-1}\right)$ and $100 \%$ (20 $\mathrm{Mg} \mathrm{ha}^{-1}$ ) of sugarcane straw left on the soil surface (mulching).

For evaluation purpose, stems of at least $2 \mathrm{~m}$ length were collected at 60,120,180, 240 and 370 days after harvest (DAH) for the first ratoon and at 60,120,180, 240 and $270 \mathrm{DAH}$ for the second ratoon. The following variables were evaluated at each sampling: number of green leaves, leaf area (LA), leaf area index (LAI), number, length $(\mathrm{m})$, diameter $(\mathrm{cm})$ and production of stems $\left(\mathrm{Mg} \mathrm{ha}^{-1}\right)$.

The average number of green leaves per tiller were determined by counting the fully expanded leaves, with a minimum $20 \%$ of green area, from the leaf +1 (Hermann and Câmara, 1999). The leaf area (LA) was calculated with the help of a leaf area meter LiCor model LI 3100, by collecting the TVD leaf ("top visible dewlap") of each existing tiller, both in the 2 linear $\mathrm{m}$ and posteriorly, using Nassif et al. (2013) methodolgy. The leaf area per tiller was calculated using the equation $\mathrm{LAT}=\mathrm{LA} \times(N+2)$, where: $\mathrm{LA}$ is the leaf area; $N$ is the number of open green leaves and 2 is the weighting factor for leaves that are not yet fully expanded. The leaf area index (LAI), evaluated only on the first ratoon, was calculated using the equation: $\mathrm{LAI}=\mathrm{NTI} \times \mathrm{LA} / A$, where: $\mathrm{NTI}$ is the number of tillers $\left(\mathrm{m}^{2}\right)$; LA is the leaf area per tiller $\left(\mathrm{m}^{2}\right)$; and $A$ is the the land area in $\mathrm{m}^{2}$ used for the evaluation.

Stems in the two linear meters of each plot were counted for obtaining the number of stems per hectare. Average stem length was calculated by measuring each stem from ground level to the first visible atrium, classified as leaf +1 . The stem diameter was measured in the middle third of the stems. Productivity was calculated from the stem weight of each evaluation period. The leaves and tips of all the stems were removed prior to weighing.

The experiment was installed in August 2010, and immediately after plantation, each straw treatment was applied to the soil. The emergence of the first ratoon occurred in September 2011 which was than harvested in December 2012. The harvest of the second ratoon occurred in October 2013. Thus, the data obtained in the first and second ratoons of sugarcane is a result of two and three years of cultivation under straw cover, respectively.

The data was analyzed using analysis of variance (ANOVA) and the means were compared via Tukey's test $(P<0.05)$ using the SISVAR software 5.0 (Ferreira, 2011).

\section{Results}

A significant effect of straw mulching was observed on the LAI in the first ratoon, at 120 and $370 \mathrm{DAH}$ (Fig. 2). In this cycle, where there was a severe water stress (Fig. 1), treatments $25 \%\left(5 \mathrm{Mg} \mathrm{ha}^{-1}\right)$ and $75 \%\left(10 \mathrm{Mg} \mathrm{ha}^{-1}\right)$ straw mulching resulted in higher LAI at $120 \mathrm{DAH}$ (6.7 and 6.8, respectively), that significantly differed from burned cane (5.3). A sharp decline was observed at $240 \mathrm{DAH}$, while at the end of the cycle (370 DAH) $50 \%$ of straw mulching resulted in the highest average (4.1), significantly higher than any other treatments, except for the $100 \%$ straw treatment (?). The burned cane presented the lowest mean value (1.9). 


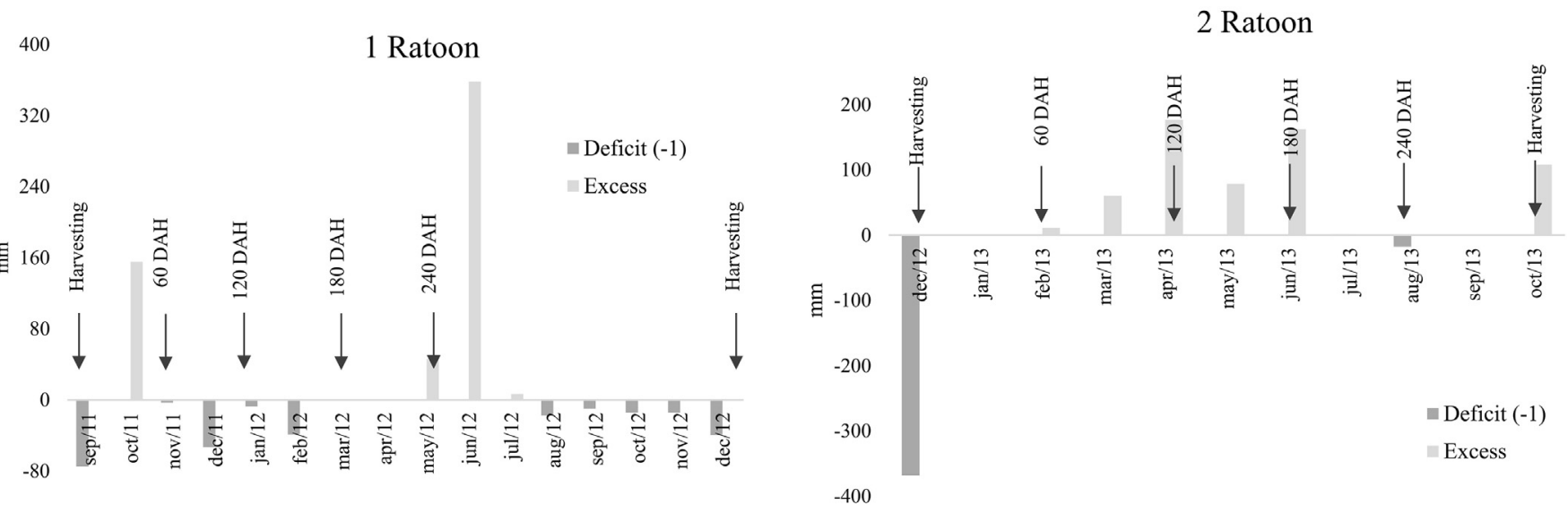

Fig. 1. Monthly water balance extract during the first and second ratoons of sugarcane cv. SP801816 grown under different amounts of straw (\%) on the soil surface.

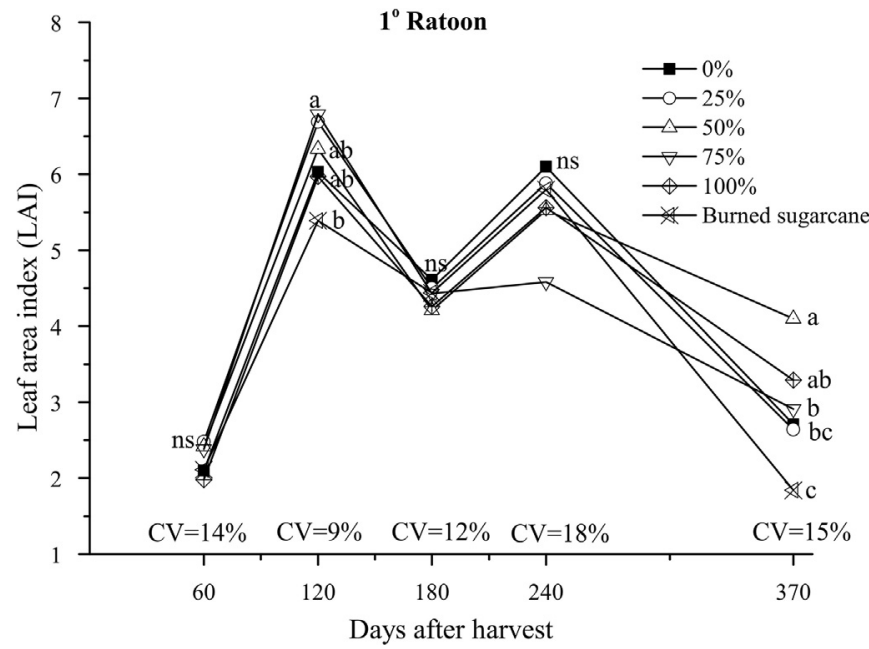

Fig. 2. Leaf area index (LAI) of sugarcane cv. SP801816 grown under different amounts of straw (\%) on the soil surface during the first ratoon (2011/12 crop). Means followed by the same letter in each date of sampling are not significantly different by Tukey's test at $5 \%$ significance level. ns: non-significant.

Stem diameter was significantly affected by straw mulching during the first ratoon at 240 and $370 \mathrm{DAH}(3.0$ and $2.95 \mathrm{~cm}$, respec- tively), with a highest mean at $240 \mathrm{DAH}$ in response to $50 \%$ of straw mulching (Fig. 3), which lasted until the end of the cycle. These means differed statistically from the ones observed for $0 \%$ straw and burned cane treatments (2.5 and 2.6 at 240 and 370 $\mathrm{DAH}$, respectively). In the second ratoon, there was no difference between treatments.

The average stem length (Fig. 4) shows growth curves with sigmoidal shape as reported by Alvarez and Castro (1999). No significant effect was observed at any time of evaluation period during both ratoon cycles.

There was significant effect of straw quantities on the number of tillers during the first ratoon cycle at 240 and 350 DAH (Fig. 5). After a decrease in the number of tillers at $180 \mathrm{DAH}$, the treatments $50 \%, 75 \%$ and $100 \%$ of straw mulching maintained higher number of tillers ( $P<0.05,99.088,95.838$ and 94.171 stems ha $^{-1}$, respectively) by the end of the cycle. Keeping $50 \%$ of straw on the soil surface resulted in $29 \%$ higher stem production than the burned cane treatment at $370 \mathrm{DAH}, 24 \%$ higher than the treatment $25 \%$ of straw mulching, and $16 \%$ higher than $0 \%$ of straw mulching treatment. The amounts higher than $50 \%$ of straw mulching did not present increase in the stems production. In the second ratoon, there was no difference between treatments.

Different amounts of straw mulching showed a significant effect on stem weight $\left(\mathrm{Mg} \mathrm{ha}^{-1}\right)$ at 240 and $370 \mathrm{DAH}$ during the first ratoon cycle (Fig. 6). At $240 \mathrm{DAH}, 50 \%$ and $75 \%$ of straw mulching
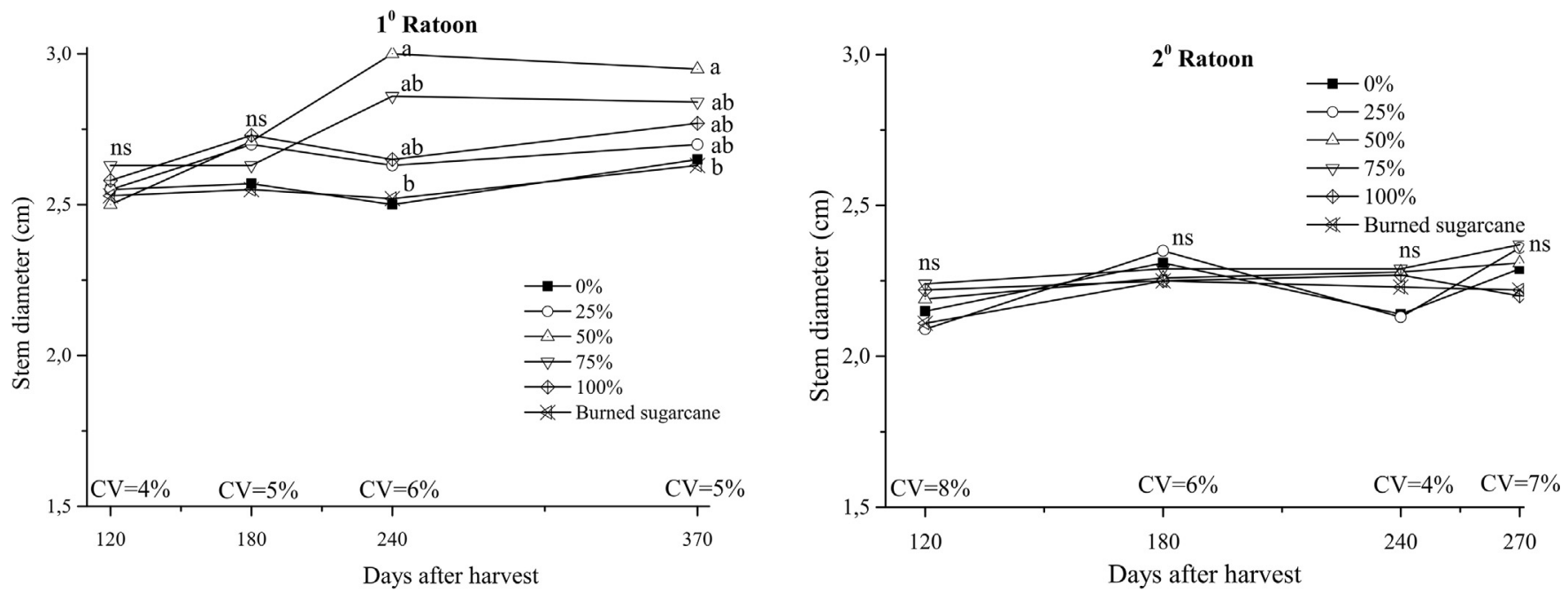

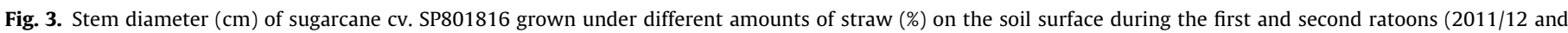
2012/13 crops). Means followed by the same letter in each date of sampling are not significantly different by Tukey's test at $5 \%$ significance level. ns: non-significant. 

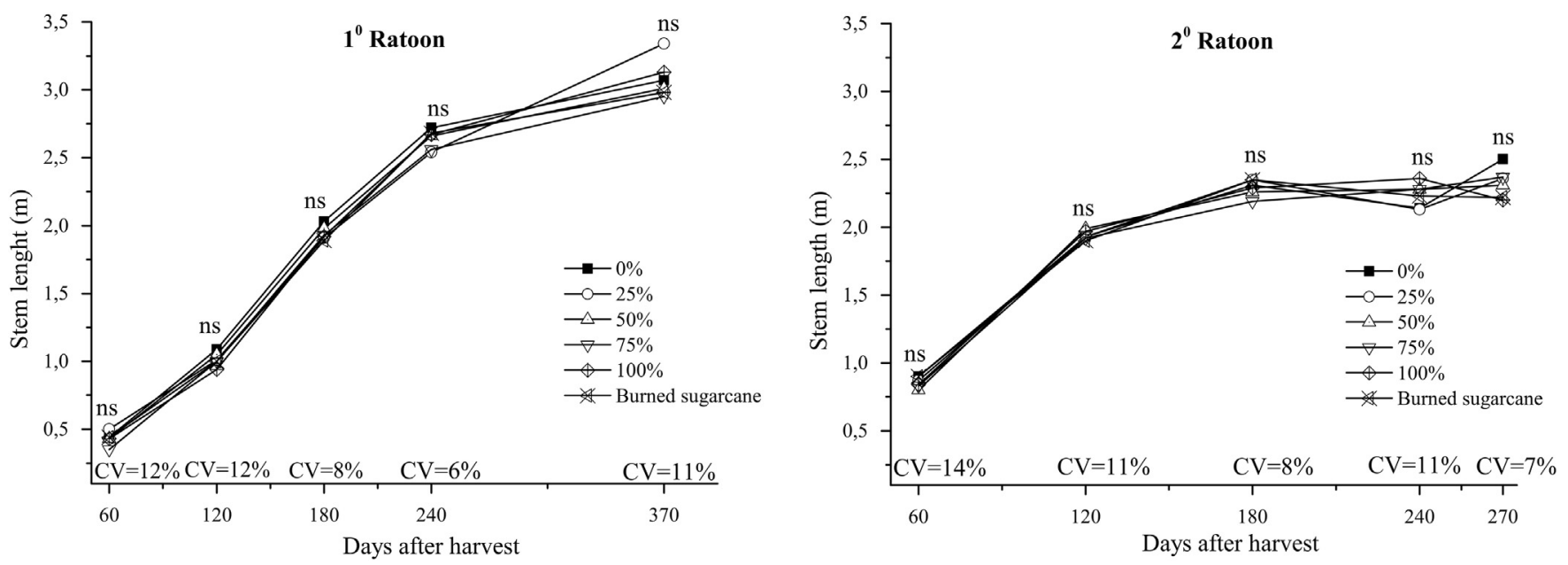

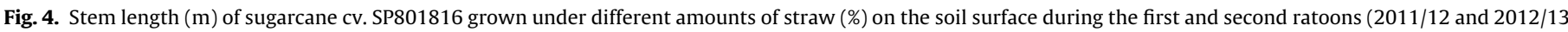
crops). ns: non-significant.
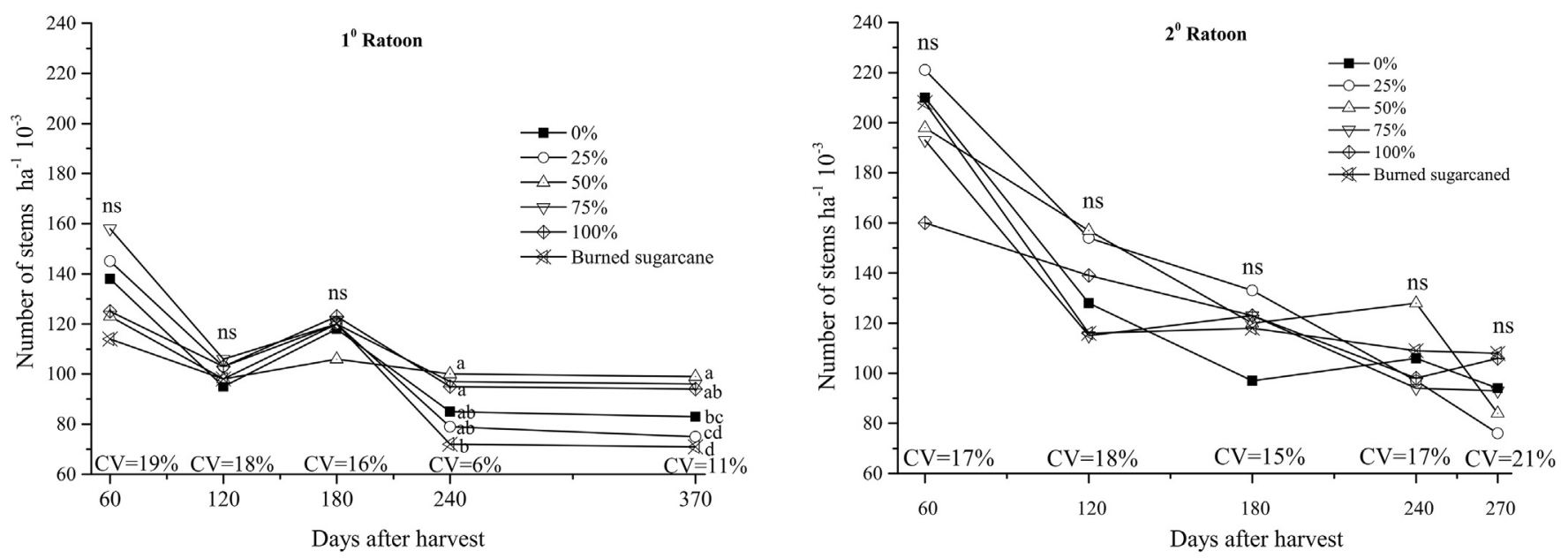

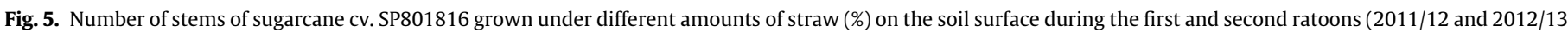
crops). Means followed by the same letter in each date of sampling are not significantly different by Tukey's test at $5 \%$ significance level. ns: non-significant.

were recorded with the highest average values $(P<0.05,127$ and $124 \mathrm{Mg} \mathrm{ha}^{-1}$, respectively), which is significantly higher than the treatments of uncovered or little covered soil i.e. burned cane, $0 \%$ and $25 \%$ straw mulching ( 88,93 and $90 \mathrm{Mg} \mathrm{ha}^{-1}$, respectively). This process continued until the end of the cycle (370 DAH) where the fresh stem weight showed an increase (Fig. 6a). Treatments $50 \%$ and $75 \%$ straw mulching showed a significantly higher average productivity of 138 and $134 \mathrm{Mg} \mathrm{ha}^{-1}$, respectively, as compared with burned cane, $0 \%$ and 25\% straw mulching (107, 102 and $109 \mathrm{Mg} \mathrm{ha}^{-1}$, respectively), which represented an increase of $22 \%$ in production. It can be observed that the lower LAI values recorded for burned sugarcane at 120 and $370 \mathrm{DAH}$ are being reflected in the form of lower average diameter and fresh weight of stems.

During the second ratoon cycle, there was no significant difference among treatments on any study period (Fig. 6), where there was surplus water available until $210 \mathrm{DAH}$, except for the initial period of sprouting (December, 2012) and in the month August, 2013 at 240 DAH (Fig. 1).

\section{Discussion}

Treatments with lower LAI mean values (Fig. 2) also resulted in lower productivity (Fig. 1, first ratoon) at the end of the cycle when there was severe drought condition. The LAI is an important factor for the evaluation of final yield, since higher values during the development cycle could be related to the higher stem production at the end (Silva and Pincelli, 2010). Oliveira et al. (2007) studied the leaf area development of three sugarcane varieties in Oxisol and correlated it with the productivity and observed that there is a significant relationship between crop yield and the IAF. Thus, the lowest LAI average observed in burned cane treatment can be highly damaging to the productivity. This may be due to the fact that after the drought when rehydration of sugarcane plants take place, the stomata can improve leaf water potential, but cannot fully recover; because the stomatal response will depend on the genotype and drought intensity, thus resulting in a severe decrease in production (Inman-Bamber and Smith, 2005).

The highest average of LAI (6.80) and a subsequent decline in its values are in line with the observations of Oliveira et al. (2007) and Farias et al. (2008). The LAI decreased with a decrease in the number of tillers per linear meter and leaf area per tiller. This phenomenon can be associated with low soil moisture contents (Farias et al., 2008), which may be the reason why higher values were observed in treatments above $50 \%$ of straw mulching. Inman-Bamber and Smith (2005) reported the same conclusions and further added that factors such as high temperatures during water stress situation can 

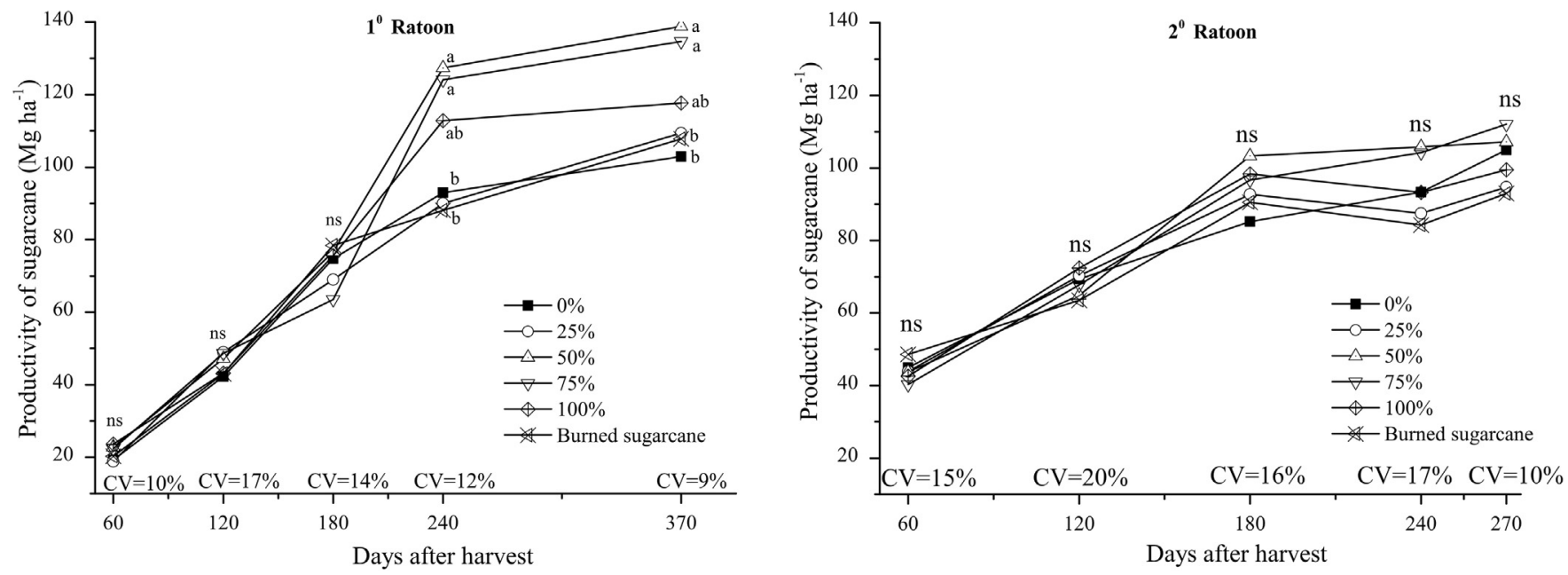

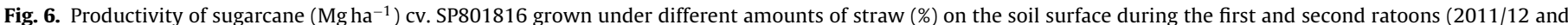
2012/13 crops). Means followed by the same letter in each date of sampling are not significantly different by Tukey's test at $5 \%$ significance level. ns: non-significant.

cause a decrease in leaf area and accelerate the senescence of green leaves.

It can be observed that $50 \%$ of straw mulching was sufficient to provide and keep a higher stem diameter until the end of the cycle during a drought period (Fig. 3, first ratoon), whereas above this amount of straw mulch, there was no superior significant response. Landell and Bressiani (2010) evaluated the biometric characteristics of 19 sugarcane genotypes in different water deficit regions and found that the stem diameter is the most sensitive of biometric indicators, one of the first parameters to show reduction in the dry season. Silva et al. (2008), evaluated different components of 80 sugarcane genotypes as drought resistance indicators, also found that the water deficiency at the initial stage affects cell division, thus reducing the diameter and weight of stems. This might be the reason why stem diameter was lower during the first ratoon, at a time when water deficiency was being observed (Fig. 1), and where the soil remained uncovered (burned sugarcane and 0\% of straw). In the second ratoon, no such behavior was observed, as there was extra water available until 210 DAH (June/2013), which is in agreement with the results reported by Silva et al. (2008) and Landel et al. (2010).

No significant effect was observed for the stem length at any time of evaluation period, on both ratoons, indicating that there was no delay in the sprouting and growth of sugarcane in relation to the amounts of straw on the soil surface, as some authors have reported (Campos et al., 2008; Campos, 2010). Landell and Bressiani (2010) observed that a decrease in soil water contents strongly affects some morphophysiological processes, while others can be relatively insensitive. They further concluded that stem length showed same behavior regardless of drought conditions. This may explain why there was no change in the stem length at first ratoon cycle, despite the occurrence of drought stress (Fig. 1). Tavares et al. (2010) investigated the effects of green and burned cane after 16 years of cultivation and also found no significant differences regarding the stem length until the $350 \mathrm{DAH}$, confirming the results of Landell and Bressiani (2010) and of this study.

It's being observed that $50 \%$ of straw mulching resulted in higher stem production during the first ratoon (Fig. 5) while no significant difference was observed among higher treatments. It is possible that the incidence of water deficiency at the first ratoon cycle may have restricted water availability to the uncovered (burned sugarcane and $0 \%$ of straw mulching), or little covered soil (25\% of straw), promoting competition among tillers and causing mortality. It can be confirmed from second ratoon, when there was a high water availability until $210 \mathrm{DAH}$, and no significant differences among treatments were observed in any of the evaluated periods (Fig. 5). It has also been observed that there was no delay or decrease in the tiller formation among different straw quantities at the beginning of the cycle. However, some studies have reported that one of the disadvantages of leaving sugarcane residue on soil surface is that it can hinder the regrowth, resulting in the reduced number of tillers (Campos, 2010; Campos et al., 2008). The failure of cane regrowth under straw has occurred only in some genotypes, evaluated under the cultivation of $100 \%$ of straw mulching, because most of the varieties have been developed at the time when burned cane system was in practice, which favor the higher rate of ratoon emergence. During this study no such behavior was observed which is in conformity with the findings of Tavares et al. (2010).

The significant effect of straw mulching on stem weight (Fig. 6) and other production components during the first ratoon cycle may be related to the water deficiency at early stages of sugarcane development, reaching up to $180 \mathrm{DAH}$ (March/2012), except for the month of October/2011. The highest level of available water was recorded only at $240 \mathrm{DAH}$. Adequate water supply at an early stage of plant growth is of key importance for proper crop development. The plant and stem production may be severely damaged due to water stress incidents at an early stage of plant growth, since the development of new shoots may be delayed or even inhibited. However, its occurrence at later stages does not significantly affect productivity (Silva et al., 2008). This phenomenon takes place because water deficiency reduces gas exchange and $\mathrm{CO}_{2}$ absorption by the leaf, thus reducing the photosynthetic activity of the plant. By removing water deficiency, the gas exchange may become normal, but it might take time and in return damage the vegetative growth of the plant during the growth cycle (Smit and Singels, 2006). This may be why lower production was observed in treatment where soil was uncovered (burned sugarcane and $0 \%$ of straw), or less covered ( $25 \%$ of straw).

Keeping straw as soil cover reduces water loss by approximately $70 \%$ and optimize the mean temperature of upper soil layers, also increase the organic matter, improves not only the soil structure but microbiota as well, ultimately increasing the crop production (Braunbeck and Magalhães, 2010). That's why during high water availability cycles, it is to be expected that among treatments there could be no difference in the productivity. 
These results indicate that the maintenance of straw residue on the soil surface has a significant effect on the farming system, which can already be seen in the short run on productivity, especially in water stress situations, as observed during this study. Another important factor to highlight here is that the burned cane harvesting system of sugarcane reduced the productivity by $22 \%$ during the water stress period. This set of information is very important for the selection of crop management system to be adopted, especially for areas where the burned sugarcane system is still permitted and it is often used previously the mechanized harvesting.

Costa et al. (2014) in simulating the effect of straw management for sugarcane productivity have observed that the total removal of straw significantly reduced sugarcane production, as compared with keeping straw residue over field, for either short or longer time period. Ball-Coelho et al. (1993) stated that, generally in sugarcane growing areas of Brazil and the world, where the rainfall is irregular or low, keeping straw as ground cover has contributed to the increase in sugarcane productivity.

However, it has not been reported so far what is the sufficient amount of straw that can bring such effects. It has been observed in this study that in drought situations, $50 \%$ of straw mulching ( $\left.10 \mathrm{Mg} \mathrm{ha}^{-1}\right)$ is enough to improve crop development and to increase productivity by $29 \%$ as compared to the burned cane system, while there was no significant effect observed above this amount of straw and therefore the surplus straw can be used for the production of electricity or second-generation ethanol, optimizing the energy production of culture, without affecting the sustainability of the farming system.

Considering that the straw plays an important role by protecting the soil from erosion (Lundy et al., 2015), which irreversibly reduces the production capability of the land. This information regarding soil cover can increase crop productivity and may stimulate growers all over the world to protect the environment, since the straw cover practice is vital when looking for the sustainability of sugarcane production system.

\section{Conclusions}

1. The replacement of burned cane harvesting system for soil management with straw, promotes benefits to the development and productivity of sugarcane ratoons.

2. Field managements with burned cane, total removal of the straw ( $0 \%$ of land cover) or keeping $25 \%$ of straw result in low number of tillers, leaf area index, stem diameter and productivity of sugarcane ratoons, under water stress conditions.

3. Keeping $50 \%$ of straw mulching is enough to improve the growth and yield of sugarcane with drought occurrences, and the remaining $50 \%$ can be used for the production of second generation ethanol or electricity without damaging the crop yield.

\section{Conflict of interest}

The authors declare that they have no conflict of interest and the authors are according to the submission.

\section{Acknowledgments}

The authors express their gratitude to Petrobras for the financial support of the research, to Coordenação de Aperfeiçoamento de Pessoal de Nivel Superior (CAPES) for the student aid, to Bandeirantes Sugar and Alcohol Plant, for disposing the experimental area and providing the technical support for evaluations, and to Embrapa Tabuleiros Costeiros for the orientation and coordination of the research.

\section{References}

Alvarez, I.A., Castro, P.R.C., 1999. Shoot growth of green and burned canes. Sci. Agric. 56 (4), 1069-1079.

Ball-Coelho, B., Tiessen, H., Stewart, J.W.B., Salcedo, I.H., Sampaio, E.V.S.B., 1993. Residue management effects on sugarcane yield and soil properties in Northeastern Brazil. Agron. J. 85 (5), 1004-1008.

Barbosa, E.A.A., Arruda, F.B., Pires, R.C.M., Silva, T.J.A., Sakai, E., 2013. Sugarcane fertigated with vinasse under subsurface drip irrigation in three cycles of cane-ratoon. Rev. Bras. Eng. Agríc. Ambient. 17 (6), 588-594.

Braunbeck, O.A., Magalhães, P.S.G., 2010. Technological evaluation of mechanization of sugarcane. In: Cortez, L.A.B. (Ed.), Bioethanol from Sugarcane: R \& D to Productivity and Sustainability. Sugarcane: R \& D to Productivity and Sustainability, Blucher, São Paulo, p. 556.

Campos, L.H.F., Carvalho, S.J.P., Christoffoleti, P.J., Fortes, C., Silva, J.S., 2008. Growth and productivity of sugarcane (var. SP83-2847) submitted to three management of straw. STAB 26 (6), 33-36.

Campos, L.H.F., 2010. Straw management systems influence biomass accumulation and yield of sugarcane crop (var. RB855453). Acta Sci. Agron. 32 (2), 345-350.

Cardoso, T.F., Cavalett, O., Chagas, M.F., Morais, E.R., Carvalho, J.L.N., Franco, H.C.J. Galdos, M.V., Scarpare, F.V., Braunbeck, O.A., Cortez, L.A.B., Bonomi, A., 2013. Technical and economic assessment of trash recovery in the sugarcane bioenergy production system. Sci. Agric. 70 (5), 353-360.

Cavenaghi, A.L., Rossi, C.V.S., Negrisoli, E., Costa, E.A.D., Velini, E.D., Toledo, R.E.B., 2007. Performance of amicarbazone applied on sugarcane straw. Planta Daninha 25 (4), 831-837.

Christoffoleti, P.J., Carvalho, S.J.P., López Ovejero, R.F., Nicolai, M., Hidalgo, E., Silva, J.E., 2007. Conservation of natural resources in Brazilian agriculture: implications on weed biology and management. Crop Prot. 26 (3), 383-389.

Costa, L.G., Marin, F.R., Nassif, D.S.P., Pinto, H.M.S., Lopes-Assad, M.L.R.C., 2014. Simulating trash and nitrogen management effects on sugarcane yield. Rev. Bras. Eng. Agríc. 18 (5), 469-474.

Embrap, A., 2013. Brazilian System of Soil Classification, 3rd ed. Embrapa, Brasília.

Farias, C.H.A., Fernandes, P.D., Azevedo, H.M., Dantas Neto, J., 2008. Growth indices of irrigated and non-irrigated sugarcane in Paraiba, Brazil. Rev. Bras. Eng. Agríc. Ambient. 12 (4), 356-362.

Franchini, J.C., Debiasi, H., Balbinot Junior, A.A., Tonon, B.C., Farias, J.R.B., Oliveira, M.C.N., Torres, E., 2012. Evolution of crop yields in different tillage and cropping systems over two decades in southern Brazil. Field Crop Res. 137, $178-185$.

Ferreira, D.F., 2011. Sisvar: a computer statistical analysis system. Ciênc. agrotec. 35 (6), 1039-1042.

Food and Agriculture Organization of the United Nations (FAO), FAOSTATS. Disponível em: 〈http://faostat.fao.org/site/567/default.aspx〉 Acesso em: 13 jan. 2016.

Garcia, J.F.G., Grisoto, E., Botelho, P.S.M., Parra, J.R.P., Appezzato-da-Glória, B., 2007. Feeding site of the spittlebug Mahanarva imbriolata (STAL) (Hemiptera: Cercopidae) on sugarcane. Sci. Agric. 64 (5), 555-557.

Guimarães, E.R., Mutton, M.A., Mutton, M.J.R., Ferro, M.I.T., Ravaneli, G.C., Silva, J.A., 2008. Free proline accumulation in sugarcane under water restriction and spittlebug infestation. Sci. Agric. 65 (6), 628-633.

Hermann, G.M.S., Câmara, E.R., 1999. A simple method to estimate the leaf area of sugarcane. STAB 17, 32-34.

Inman-Bamber, N.G., Smith, D.M., 2005. Water relations in sugarcane and response to water deficits. Field Crop Res. 92 (2), 185-202.

Landell, M.G.A., Bressiani, J.A., 2010. Genetic Improvement, Characterization and Management Varietal. In: Dinardo-Miranda, L.L., Vasconcelos, A.C.M., Landell M.G.A. (Eds.), Sugarcane. Agronomic Institute, Campinas.

Lundya, M.E., Pittelkowc, C.M., Linquist, B.A., Liang, X., Groenigene, K.J., Leef, J., Sixf, J., Venterea, R.T., Kessel, C.V., 2015. Nitrogen fertilization reduces yield declines following no-till adoption. Field Crop Res. 183, 204-210.

Marin, F.R., Martha Junior, G.B., Cassman, K.G., Grassini, P., 2016. Prospects for increasing sugarcane and bioethanol production on existing crop area in Brazil. BioScience 66 (4), 307-316.

Nassif, D.S., Marin, F.R., Costa, L.G., 2013. Minimum Standards for the Collection of Experimental Data for Studies on Growth and Development of the Culture of Sugarcane, 127th ed. Embrapa Agriculture Informatics, Campinas.

Oliveira, O.C., Urquiaga, S.S., Boddey, R.M., 1995. La quema de la caña: efectos a largo plazo. Int. Sugar J. 97 (1160), 384-387.

Oliveira, M.W., Barbosa, M.H.P., Mendes, L.C., Damasceno, C.M., 2003. Dry matter and nutrients in straw ten varieties of sugarcane. STAB 21 (3), 30-31.

Oliveira, R.A., Daros, E., Zambon, J.L.C., Weber, H., Ido, O.T., Bespalhok-Filho, J.C., Zuffellato-Ribas, K.C., Silva, D.K.T., 2007. Leaf area in three sugar-cane cultivars and its relationship with biomass production. Pesqui. Agropecu. Trop. 37 (2), 71-76.

Otto, R., Castro, S.A.Q., Mariano, E., Castro, S.G.Q., Franco, H.C.J., Trivelin, P.C.O., 2016. Prospects for increasing sugarcane and bioethanol production on existing crop area in Brazil. BioScience 66 (4), 307-316.

Resende, A.S., Santos, A., Xavier, R.P., Coelho, C.H., Gondim, A., Oliveira, O.C., Alves, B.J.R., Boddey, R.M., 2006. Effect of pre-harvest burning and applications of nitrogen fertilizer and vinasse on sugarcane industrial characteristics. Rev. Bras. Cienc. Solo 30 (6), 937-941.

Santos, F.A., Queiróz, J.H., Colodette, J.L., Fernandes, S.A., Guimarães, V.M., Rezende, S.T., 2012. Potential of sugarcane straw for ethanol production. Quim. Nova 35 (5), 1004-1010. 
Silva, M.A., Silva, J.A.G., Enciso, J., Sharma, V., Jifon, J., 2008. Yield components as indicators of drought tolerance of sugarcane. Sci. Agric. 65 (6), 620-627.

Silva, M.A., Pincelli, R.P., et al., 2010. Morphological and physiological changes in sugarcane in response to water deficit. In: CRUSCIOL (Ed.), Ecophysiology of Sugarcane. FEPAF, Botucatu.

Smit, Singels, M.A.A., 2006. The response of surgarcane canopy development to water stress. In: Field Crops Research. Cambridge, 98, pp. 91-97.

Souza, Z.M., Prado, R.M., Paixão, A.C.S., Cesarin, L.G., 2005. Harvest systems and residue management of sugarcane. Pesqui. Agropecu. Bras. 40 (3), 271-278.
Tavares, O.C.H., Lima, E., Zonta, E., 2010. Sugarcane growth and productivity under different tillage and crop systems. Acta Sci. 32 (1), 61-68.

Thornthwaite, C.W., Mather, J.R., 1955. The Water Balance (Publications in

Climatology). Drexel Institute of Technology, New Jersey.

UNICA; Sustentabilidade São Paulo fecha safra 2013/2014 com colheita mecanizada em $83 \%$ dos canaviais. Available at:

/http://www.unica.com.br/noticia/6551584920310621254/sao-paulo-fechasafra-2013-por-cento2F2014-com-colheita-mecanizada-em-83-por-centodos-canaviais/> (accessed 10.12.15). 